\title{
ФОРМУВАННЯ ПРОФЕСІЙНОӤ КОМПЕТЕНТНОСТІ МАЙБУТНІХ УЧИТЕЛІВ ПОЧАТКОВОЇ ШКОЛИ В УМОВАХ ДИСТАНЦЙНОГО НАВЧАННЯ У ФАХОВОМУ ПЕДАГОГІЧНОМУ КОЛЕДЖІ
}

\author{
Гоцуляк К. I. \\ кандидат педагогічних наук, \\ викладач \\ Івано-Франківський фаховий коледж \\ Прикарпатського начіонального університету імені Василя Стефаника \\ вул. Шевченка, 57, Івано-Франківськ, Украӥна \\ orcid.org/0000-0001-5413-0482 \\ kateryna.hotsuliak@pnu.edu.ua \\ Стамбульська T. I. \\ кандидат педагогічних наук, \\ викладач \\ Івано-Франківський фаховий коледж \\ Прикарпатського національного університету імені Василя Стефаника \\ вул. Шевченка, 57, Івано-Франківськ, Україна \\ orcid.org/0000-0002-9904-8324 \\ tetyana.stambulska@pnu.edu.ua
}

\begin{abstract}
Ключові слова: вчитель початкової школи, дистаниійне навчання, дистаниійна освіта, інновації, Інтернет, інформаційнокомунікаційні технології, професійна компетентність, фаховий коледж.
\end{abstract}

Діджиталізація освіти, використання все новіших i сучасніших інформаційно-комунікаційних технологій та укорінення глобальної мережі Інтернет як основи здобуття освіти призвели до змін у традиційних моделях навчання, тому у вищих школах можна розвивати новий напрям дистанційного навчання, який базується на комп'ютерних та телекомунікаційних технологіях: масове запровадження для здобуття освіти різноманітних відеоплатформ, можливість розміщувати відеолекції чи електронне навчально-методичне забезпечення на сайті закладу чи на хмарних сховищах, комунікування зі студентами та колегами у різних месенджерах.

Цифрова трансформація інформації у ЗФПО вимагає від здобувачів освіти вміння отримувати іiі, працювати 3 нею та засвоювати критично й самостійно. Цього вимагає і система навчання у ЗФПО у період карантину, що диктує основи професійної компетентності майбутніх учителів початкової школи.

Сьогодні все більше українських дослідників підтримують ідею запровадження та розвитку дистанційного навчання як важливої частини освітньої галузі. Через пандемію в Україні та в усьому світі використання дистанційної освіти набуло особливого значення під час тривалої ізоляції. 3 одного боку, навчальні заклади задовольняють свої потреби участі у відкритому інформаційному просторі, а з іншого - надають можливості для досягнення освітніх цілей за допомогою IКТ.

У статті визначено сутність поняття «формування професійної компетентності майбутніх учителів початкової школи в умовах пандемії». Багато труднощів та недоліків було виявлено під час здійснення дистанційного навчання: проблема наступності в педагогічній освіті (змісту, методів, форм), змісту навчального матеріалу на різних рівнях вищої освіти; домінування репродуктивних методів та форм навчання; 
слабка орієнтація підготовки на майбутню професію, неможливість здійснювати навчання у дистанційній формі на однаковому рівні для всіх студентів та обмеженість в ефективному та адекватному оцінюванні результатів дистанційного навчання здобувачів освіти.

Нами використано теоретичні методи для розв'язання дослідницьких завдань: аналізу та систематизації літератури 3 психології, педагогіки та методики для визначення стану і теоретичної основи формування проблем у професійних здібностях майбутніх учителів початкових класів у сучасних навчальних закладах. Визначено поняття компетентності вчителів початкових класів та вивчено можливість формування професії та культури викладання у сучасних коледжах.

\title{
FORMATION OF PROFESSIONAL COMPETENCE OF FUTURE PRIMARY SCHOOL TEACHERS IN THE CONDITIONS OF DISTANCE LEARNING IN A PROFESSIONAL PEDAGOGICAL COLLEGE
}

\author{
Hotsuliak K. I. \\ Candidate of Pedagogical Sciences, \\ Lecturer \\ Ivano-Frankivsk Professional College \\ of Vasyl Stefanyk Precarpathian National University \\ Shevchenko str., 57, Ivano-Frankivsk, Ukraine \\ orcid.org/0000-0001-5413-0482 \\ Kate81@i.ua \\ Stambulska T. I. \\ Candidate of Pedagogical Sciences, \\ Lecturer \\ Ivano-Frankivsk Professional College \\ of Vasyl Stefanyk Precarpathian National University \\ Shevchenko str., 57, Ivano-Frankivsk, Ukraine \\ orcid.org/0000-0002-9904-8324 \\ tanyastamb13@gmail.com
}

Key words: primary school teacher, distance learning, distance education, innovation, Internet, information and communication technologies, professional competence, vocational college.
The digitalization of education, the use of newer and more modern information and communication technologies and the introduction of the global Internet as the basis for education have led to changes in traditional learning models. Therefore, in higher education it is possible to develop a new direction of distance learning, which is based on computer and telecommunication technologies: mass introduction for education of various video platforms, possibility to place video lectures or e-learning on the site or in cloud storage, communication with students and colleagues in different messengers.

The digital transformation of information in professional College requires from students the ability to receive, work with it and assimilate critically and independently. This is required by the system of education in professional College during the quarantine period, which dictates the basics of professional competence of future primary school teachers.

Today, more and more Ukrainian researchers support the idea of introducing and developing distance learning as an important part of education. Due to the pandemic in Ukraine and around the world, the use of distance education has become especially important during prolonged isolation. On the one hand, educational institutions meet their needs to participate in the open information 
space, and on the other - provide opportunities to achieve educational goals through ICT.

The article defines the essence formation of professional competence of future primary school teachers in a pandemic. Many difficulties and shortcomings were identified in the implementation of distance learning: the problem of continuity in pedagogical education (content, methods, forms), the content of educational material at different levels of higher education; dominance of reproductive methods and forms of education; weak orientation of training for the future profession, the inability to carry out distance learning at the same level for all students and limited effective and adequate assessment of the results of distance learning for students.

The urgency of the problem of formation of professional competence of future primary school teachers in distance learning in a professional pedagogical college is due to contradictions between: growing needs of society in teachers of new formation, capable of implementing modern ICT and insufficient development of theoretical and methodological principles of their training in higher pedagogical education; growing demands on the level of formation of information competence in future primary school teachers and insufficient development of theoretical and methodological principles of its formation, unwillingness of higher education and university teachers to study online during quarantine.

We used theoretical methods to solve research problems: analysis and systematization of literature on psychology, pedagogy and methods to determine the state and theoretical basis for the formation of problems in the professional abilities of future primary school teachers in modern schools. The concept of competence of primary school teachers is defined and the possibility of formation of profession and culture of teaching in modern colleges is studied.

Постановка проблеми. Розвиток дистанційної освіти відображається на законодавчому рівні, особливо в Указі Президента «Про заходи щодо розвитку національної складової глобальної інформаційної мережі Інтернет та забезпечення широкого доступу до цієї мережі в Україні» (2000р.), Концепції розвитку дистанційної освіти в Україні (2000р.), Наказі Міністерства освіти і науки України «Про затвердження Положення про дистанційне навчання» (2013р.), Законі України «Про вищу освіту» (2014 р.).

У Положенні про дистанційне навчання говориться: «Під дистанційним навчанням розуміється індивідуалізований процес набуття знань, умінь, навичок і способів пізнавальної діяльності людини, який відбувається переважно за опосередкованої взаємодії віддалених один від одного учасників навчального процесу у спеціалізованому середовищі, яке функціонує на базі сучасних психолого-педагогічних та інформаційно-комунікаційних технологій» [1, с. 2].

Як правило, використання інформаційнокомунікаційних технологій у навчальному процесі обмежується пошуком інформації та забезпеченням зв'язку між об'єктами навчального процесу. Однак сфера їх застосування набагато ширша і повинна спрямовуватися на формування високої інформаційної культури для майбутніх учителів, яка забезпечує умови для їхніх професійних здібностей. Сучасні вчителі повинні мати не лише практичні навички пошуку, зберігання та обробки інформації, а й здатність вибирати найкращу форму представлення та прийняття на основі ефективного прийняття рішень.

Одні 3 важливих способів організації дистанційного навчання вчителя - сприяння ефективній роботі вчителів та учнів у процесі формування їхньої професійної компетентності та цілеспрямоване створення інформаційно-комунікаційних технологій для підтримки системи навчального процесу.

Такі навчальні курси мають включати теоретичну та практичну підготовку вчителя, який використовує у професійній діяльності сучасні IKT, оскільки ресурси електронного навчання можна використовувати як інструмент для вчителів та грамотної організації роботи зі студентами.

Аналіз останніх досліджень і публікацій. Н. Бібік, Л. Коваль, О. Пометун, О. Савченко, С. Стрілець, Л. Хомич, І. Шапошнікова та ін. вивчали питання професійної підготовки майбутніх учителів початкових класів; В. Бондар, I. Зязюн, Н. Ничкало, С. Сисоєва досліджували особливості формування творчої особистості вчителів в інформаційному суспільстві. Проблемою підвищення ефективності навчання завдяки вико- 
ристанню інформаційних технологій та формуванню комп'ютерних знань займалися В. Биков, Р. Гуревич, А. Гуржій, Є. Полат та А. Хуторський; питання щодо методів та технічних аспектів дистанційного навчання піднімали А. Андрєєва, Д. Богданова, В. Макарова.

Мета статті - обгрунтувати основи формування професійної компетентності майбутніх учителів за умов дистанційного навчання та визначити напрям онлайн-роботи у фаховому педагогічному коледжі, котрий сприятиме свідомому оволодінню професією майбутніх педагогів.

Виклад основного матеріалу. У сучасних умовах інформаційного суспільства необхідно готувати нових фахівців, котрі зможуть використовувати інформаційно-комунікаційні технології в навчанні та майбутній професійній діяльності для досягнення самовдосконалення, самореалізації, самоосвіти та подальшого професійного розвитку.

У цьому разі, відповідно до потреб сучасного суспільства у розвитку дистанційного навчання, підвищення якості професійної підготовки вчителів початкових класів у майбутньому допоможе формуванню вибраної професії.

Отже, передумовами розвитку дистанційного навчання на рівні здобуття освіти у фаховому педагогічному коледжі $є$ :

- швидкий розвиток інформаційних технологій;

- поступове та постійне зниження вартості послуг, що використовуються для підключення та використання глобальної мережі Інтернет, іiі ресурсів та послуг;

- значне поглиблення впровадження інформаційних технологій в освітній практиці;

- масове поширення комп'ютерної техніки серед населення;

- запровадження карантину та розмежовування території на зони через пандемію COVID-19.

Дистанційне навчання з'являється як спеціальна технологія навчання у XXI ст. Вона базується на відкритому навчанні 3 використанням широкого спектру традиційних та сучасних інформаційних технологій та його технічних засобів для забезпечення структурованих навчальних матеріалів. В електронній формі це самостійна обробка та навчання, діалог та обмін між викладачем та здобувачем освіти, який навчається в інформаційному просторі.

Дистанційна освіта може бути використана як форма та техніка навчання (електронне навчання). $\mathrm{У}$ цьому разі немає проблеми переоцінити роль здобувачів у навчальному процесі, оскільки технологія електронного навчання використовується як допоміжний засіб у звичайній системі взаємодії «педагог - здобувач». Це вимагає необхідного запасу знань, які неможливо отримати без інформаційно-комунікаційних технологій.
Ми переконані, що студенти повинні розвивати необхідні навички та вміння, щоб використовувати їх у навчанні, пізнанні та майбутній професійній діяльності. Фундаментом навчальної діяльності $є$ розвиток пізнавальних здібностей, самостійна побудова знань, уміння орієнтуватися в інформаційному просторі, розвиток критичного та творчого мислення, не лише здатність виявляти та вирішувати проблеми, а й здатність знаходити способи їх розумного вирішення [3].

Слід підкреслити, що сучасна система вищої освіти, а особливо фахові коледжі, переважно зорієнтовані на формування професійних можливостей майбутніх експертів. Під професійними здібностями вчителя розуміють сукупність його особистих якостей, професійних знань, умінь, загальнокультурних та методичних навичок, оскільки здатність проявляється в діяльності людини, але якщо немає набору знань для визначення та свідомого вибору дій, учинків, не вдасться досягти конкретних операцій та виконання.

Відзначимо, що в науці не існує чіткого методу визначення понять «здатність» та «професійна здатність». Зазвичай науковий аналіз професійної компетентності вчителів може представити іiі у багатьох аспектах. У нашому уявленні професійні здібності - це складне особисте, професійне та інтелектуальне формування, це професійна діяльність, яка формується, втілюється та вдосконалюється у процесі навчання. Це єдність знань, необхідних для успішного здійснення професійної діяльності та досвіду. Вона передбачає не лише володіння необхідними практичними вміннями та навичками, а й наявність професійного поля професійного значення - щодо цілей, цінностей, змісту та характеристики цієї діяльності, характеру майбутньої професійної діяльності [4, с. 115].

Дослідники постійно розробляють та вдосконалюють ключові компоненти професійної компетентності вчителів, тому ефективність процесу формування професійної компетентності майбутніх учителів у системіпрофесійноїпідготовкизалежатиме від цілісності всіх іiі компонентів. Зрештою, це поняття $\epsilon$ динамічним та багатогранним, і його зміст та структура можуть бути змінені та скориговані швидким розвитком науки і практики, можливістю та умовами здобуття освіти (у нашому разі - у період карантинних обмежень та неможливості здійснювати безпосереднє навчання).

Однак сьогодні не розроблено таких методів здобуття освіти, які б сприяли формуванню професійної компетентності майбутніх учителів початкових класів під час дистанційного навчання у фаховому педагогічному коледжі, тому ми розглядаємо гармонійне поєднання в процесі навчання технології дистанційного навчання і формування професійної здатності учнів до іiі реалізації, що 
підвищить ефективність навчання в освітньому процесі. Інформаційна культура майбутніх учителів стала важливим складником їхньої професійної культури, тому у вищій школі дистанційне навчання $є$ не лише новою технологією, а й об'єктом навчання та застосування в освітньому процесі студентів у циклі вивчення різних дисциплін.

Ми встановили специфіку професійної діяльності вчителя початкової школи в умовах упровадження нового Державного стандарту початкової освіти, реалізації положень Концепції НУШ. Це зумовлюється складністю iï інтегрованого характеру: викладанням учителем до 12 дисциплін, що вимагає якісної внутрішньопредметної та міжпредметної інтеграції, орієнтованої на формування в учнів цілісної картини світу; спрямованість на врахування психологічних особливостей сучасних дітей, які народилися та навчаються в інформаційно-технологічну епоху й характеризуються невичерпними пізнавальними можливостями, максимальною готовністю до пізнання нового, безпосередністю й емоційністю, креативністю образного мислення, легкістю сприйняття та цікавістю до використання IКТ тощо.

Усе це вимагає від учителя початкової школи наявності яскраво-образного мислення, здатності зацікавити учнів освітнім процесом, схильності до використання ігрових методів навчання, дотримання ролі педагога-фасилітатора, опанування методик викладання дисциплін, які вивчаються в початковій школі, здатності викладати навчальний матеріал з упровадженням сучасних засобів ІКТ тощо.

Науковцями, зокрема О. Перець, $з$ якою ми погоджуємося, визначено основні підходи до вирішення проблеми дослідження, а саме: системний (забезпечує дослідження системоутворювальних зв'язків процесу формування інформаційної компетентності майбутніх учителів початкової школи); особистісно-діяльнісний (передбачає практичну спрямованість процесу підготовки майбутніх учителів початкової школи на формування вмінь використання засобів ІКТ у професійно-педагогічній діяльності); компетентнісний (забезпечує готовність майбутніх учителів початкової школи якісно здійснювати професійну діяльність); акмеологічний (передбачає здатність до самореалізації та самовираження, самоконтролю і самооцінки, постійного самовдосконалення 3 метою досягнення успіху, педагогічної рефлексії) [2].

Окрім цього, ми виокремили рівні та показники сформованості професійної компетентності майбутнього вчителя початкової школи у фаховому педагогічному коледжі, яких може досягнути студент в умовах дистанційного навчання.

Інтеграція української освіти в європейське освітнє поле вимагає підготовки педагогів нового покоління. Потрібно вміти сформувати команду кваліфікованих та високоякісних конкурентоспроможних фахівців, які можуть відповідати міжнародним вимогам та стандартам якості. Важливу роль у цьому процесі відіграє вища освіта, головним завданням якої є створення умов для ефективного формування та розвитку професійних здібностей майбутніх учителів. Ефективність майбутньої професійної підготовки фахівців в умовах онлайн-навчання та загальна якість освіти залежать від рівня професійної компетентності сучасних викладачів.

Дослідження професійної компетентності фахівців стають дедалі актуальнішими. Інноваційне суспільство вимагає постійного вдосконалення професійних здібностей викладачів, що призводить до необхідності визначення певних рівнів, критеріїв та показників, тому в структурі професійної компетентності майбутніх учителів початкових класів ми виділяємо такі компоненти, як мотиваційно-ціннісний, змістовий, операційно-діяльнісний, рефлексивний та особистісний.

Сутність мотиваційно-ціннісного компонента полягає у визначенні мети, соціальних установок, ціннісних орієнтацій, потреб, інтересів, нахилів, мотивів, які спонукають до професійної діяльності та визначають професійну спрямованість певної особистості. Змістовий компонент включає такі елементи компетентності: обізнаність, оволодіння професійними та загальнонауковими знаннями і певним досвідом, норми професії, педагогічне мислення, соціальні функції сучасного вчителя. В основі операційно-діяльнісного компонента - професійно-педагогічні вміння педагога опановувати педагогічні технології. Особистісний компонент майбутнього вчителя початкових класів повинен бути пов'язаний з особистісними та професійними якостями та здібностями особистості, які впливають на результат його діяльності та визначають індивідуальний стиль кожного педагога. Рефлексивний компонент - це вміння свідомо контролювати й здійснювати критичний та творчий аналіз результатів діяльності і рівня особистісних досягнень та власного розвитку.

На основі визначених компонентів та показників професійної компетентності необхідно визначити рівень сформованості професійних можливостей майбутніх учителів, які навчаються у фаховому педагогічному коледжі. Загалом у вчених $є$ багато поглядів із приводу такого поділу, i вони виділяють рівні професійної компетентності від найвищого до найнижчого, кожен з яких зосереджується на конкретному наборі вмінь та навичок, яких міг досягнути здобувач освіти у період дистанційного навчання. Зрозуміло, що кожен рівень представлений набором як базових здібностей та навичок, так і оперативних, критичних можливостей. 
Якщо говорити про досвід формування професійної компетентності майбутніх учителів початкової школи в умовах дистанційного навчання у фаховому педагогічному коледжі тепер, у період карантину, то ми стикнулися з тим, що рівень опанування здобувачами освіти професійних навичок під час очного навчання, безпосередньої взаємодії з викладачем та комунікування зі студентами-колегами $\epsilon$ значно вищим. Зрозуміло, що більшість закладів вищої освіти зробила доступними для своїх студентів онлайн-лекції, які можна дивитися у режимі реального часу (спілкування викладача зі студентами через відеоплатформи тут і зараз), проте лекція в аудиторії передає більш унаочнене розуміння того, хто такий педагог і які професійні навички йому властиві.

Нестійкий зв'язок між учасниками відеочату, неможливість студента зосередитися на навчанні через побутові «доповнення» тощо впливають на якість формування тих чи інших навичок.

Висновки і пропозиції. Аналіз результатів нашої роботи показує, що за допомогою різних форм та методів дистанційного навчання в системі освіти цілеспрямовано можуть формуватися професійні здібності майбутніх учителів початкових класів, що допоможе випускникам коледжів підготуватися до викладання в школах.
Для досягнення ефективних результатів навчання проводилися відеолекції, семінари та практичні заняття, круглі столи, групова співпраця, студенти брали участь у дослідженнях, онлайн-конкурсах, наукових конференціях, конкурсах навичок викладання, тематичних заходах тощо. Цей вид роботи сприяє свідомому опанування професії, підвищує інтерес до діяльності вчителів початкових класів, стимулює прагнення до самоконтролю, саморозвитку та самовдосконалення, розвиває спілкування, творчість, креативність та виховує поведінкові навички культури тощо.

Результати нашого дослідження доводять, що запропонована та перевірена технологія, яка впроваджена під час дистанційного навчання, може бути використана для формування професійних здібностей майбутніх учителів початкових класів у фахових коледжах та університетах, і вона $€$ ефективною та доцільною.

Таким чином, означені критерії, рівні та показники сформованості професійної компетентності майбутнього вчителя початкових класів забезпечать можливість проведення моніторингових досліджень із даної проблематики, що й є перспективою подальших пошуків у цьому напрямі 3 метою визначення шляхів для підвищення рівня професійної компетентності студента фахового педагогічного коледжу.

\section{ЛІТЕРАТУРА}

1. Про внесення змін до Положення про дистанційне навчання : Наказ Міністерства освіти і науки України від 01 червня 2013 року № 660. URL: http://zakon2.rada.gov.ua/laws/show/z0910-13.

2. Перець О. Основні критерії, рівні та показники сформованості професійної компетентності майбутнього вчителя початкових класів. Проблеми підготовки сучасного вчителя. 2010. № 2. С. 119-125.

3. Стрілець С.І. Інновації у вищій педагогічній освіті: теорія і практика : навчальний посібник. Чернігів : ФОП Лозовий В.М., 2013. 508 с.

4. Сучасна парадигма формування професіоналізму майбутніх фахівців : зб. наук. праць за матеріалами Всеукр. наук.-практ. Інтернет-конф., 20-21 квітня 2011 р. / ДВНЗ «Переяслав Хмельницький державний педагогічний ун-т імені Григорія Сковороди» ; ред. В.П. Коцур, Д.С. Мазоха. Київ : Міленіум, 2011. 216 с.

\section{REFERENCES}

1. Pro vnesennya zmin do Polozhennya pro dystancijne navchannya [On amendments to the Regulations on distance learning] : nakaz Ministerstva osvity i nauky Ukrayiny of June 1. 2013. № 660. URL : http://zakon2.rada.gov.ua/laws/show/z0910-13.

2. Perecj O. (2010). Osnovni kryteriji, rivni ta pokaznyky sformovanosti profesijnoji kompetentnosti majbutnjogho vchytelja pochatkovykh klasiv [The main criteria, levels and indicators of professional competence of the future primary school teacher]. Problemy pidghotovky suchasnogho vchytelja. № 2. P. 119-125 [in Ukrainian].

3. Strilecj S.I. (2013). Innovaciji u vyshhij pedaghoghichnij osviti: teorija i praktyka : navchaljnyj posibnyk dlja studentiv vyshhykh navchaljnykh zakladiv [Innovation in higher pedagogical education: theory and practice: navchaljnyj posibnyk for students vyshhykh navchaljnykh zakladiv]. Chernighiv : FOP Lozovyj V.M. 508 p. [in Ukrainian].

4. Suchasna paradyghma formuvannja profesionalizmu majbutnikh fakhivciv: zb. nauk. pracj za materialamy Vseukr. nauk.-prakt. internet-konf., 20-21 kvitnja 2011 r. / M-vo osvity i nauky, molodi ta sportu Ukrajiny, DVNZ «Perejaslav Khmeljnycjkyj derzhavnyj pedaghoghichnyj un-t imeni Ghryghorija Skovorody» [Modern paradigm of formation of professionalism of future specialists: coll. Science. works on the materials of All-Ukrainian. scientific-practical Internet conference, April 20-21, 2011 / Ministry of Education and Science, Youth and Sports of Ukraine, Pereyaslav Khmelnytsky State Pedagogical University named after Hryhoriy Skovoroda]. / red. V.P. Kocur, D.S. Mazokha]. Kyjiv : Milenium, 2011. 216 p. [in Ukrainian]. 